\title{
Cultural Diplomacy and Brancusi's Reception in the Digital Age in Romania
}

\author{
Nicolae Stanciu \\ "Dunărea de Jos (Lower Danube)" University of Galati
}

\begin{abstract}
The internet and media resources have opened new opportunities for digital cultural diplomacy and management of culture. Theoretically an ideal choice for cultural diplomacy, Constantin Brancusi's reputation as a representative for government agency has suffered a crisis of reception. A Romanian-born and French-adopted sculptor, Brancusi has become a symbol of folklore and mythology but also a great, internationally recognized sculptor. This has been due to the existence of preferred or fixed models of desigining projects instead of involving teams of different backgrounds and incorporating cultural concepts in the political discourse. Approaching the topic with concepts of cultural diplomacy, media anthropology, heritage and online discourse, this case study deals with media events of cultural diplomacy broadcasted online in present day Romania. It emphasizes the potential that lies in cultural management and the important role of team spirit in designing public cultural policies and implementing projects.
\end{abstract}

Keywords: cultural creativity, diplomacy and management, digital resources as means of promotion, heritage recovery, marketing culture, international visibility.

Résumé: Les sources internet et médiatiques ont ouvert la voie à de nouvelles opportunités pour la diplomatie culturelle numérique et la gestion de la culture. Même s'il est théoriquement un choix idéal pour la diplomatie culturelle, la réputation de Constantin Brancusi en tant que représentant d'agence gouvernementale a souffert d'un déficit d'accueil. Sculpteur roumain d'origine et naturalisé français, Brancusi est devenu un symbole de folklore et de mythologie mais aussi, un sculpteur mondialement reconnu. Cette situation s'explique par l'existence de modèles fixes ou privilégiés de conceptions de projets au lieu d'impliquer des équipes d'horizons différents et d'incorporer des concepts culturels aux discours politiques. En mobilisant le concept de diplomatie culturelle, l'anthropologie des médias et les discours numériques du patrimoine, cette étude de cas s'intéresse aux évènements médiatiques et virtuels qui ont cours dans la Roumanie contemporaine. Elle souligne le potentiel qui relie la gestion du secteur culturel et le rôle important de l'esprit d'équipe dans la conceptualisation et la réalisation de projets de politiques publiques culturelles.

Mots clé: créativité culturelle, diplomatie et gestion, ressources numériques comme moyen de promotion, réappropriation du patrimoine, marketing culturel, visibilité internationale.

\section{A life journey into carving art perfection promoted through digital media and social network}

This article aims at a critical analysis of cultural diplomacy development in Romania today, underlining the causes of cutbacks and lack of modern concepts in cultural policies. Taking as a model, media

Nicolae Stanciu is a Professor at the Center of Discourse Analysis and Practice, University of "Dunarea de Jos" (Lower Danube), Galati, Romania. Email: nickstanciu@gmail.com.

Culture and Local Governance / Culture et gouvernance locale, vol. 7, no. 1-2, 2020. ISSN 1911-7469

Centre on Governance, University of Ottawa, 120 university, Ottawa, Ontario, Canada K1N 6N5. 
events that focus on meandering integration and promotion through cultural diplomacy using the posthumous memory of a Romanian sculptor, the author attempts to identify the causes of holdbacks in the field of cultural management and national policies.

Born in a small village in Gorj county, Hobița, under the astral protection of Piesci (Șușara, 2020: 5), Constantin Brâncuși became the "inventor of modern scupture" (Tabart, 1995, p.69). His art combines Romanian folk and universal archetypes into a fluid, graceful and symbolic manifestation of 'real as essence of phenomena' (Brâncusi's aphorisms apud Zărnescu, 2004, p. 125). His carvings and drawings, whose main subjects are birds, infancy, eggs, fish, kissing, flight, muses, and sleep, suggest an aspiration for perfection. Friendly interactions with famous French bohemians (Amedeo Modigliani, Fernard Léger, Henri Matisse, Henri-Pierre Roché, Marcel Duchamp), with buyers of his sculptures (John Quinn), mentors (Léon Bonnat, Auguste Rodin), models (Renée Frachon, Margit Pogany) and visitors (Ezra Pound, James Joyce) to his Parisian workshops thrust Brancusi into the limelight and promoted his reputaton as an international artist.

This sculptor, who intended to cultivate a cosmopolitan persona, is instead posthumously remembered as an interesting antithetical combination of "a rural person of antique type and a modern artist" (Pandrea, 2010, p.21). A broad variety of opinions regarding his personality include the following: a "Romanian peasant" (Eliade, 1967, p.33), who absorbed traditional images and projected them into universal sculpture, an "alchemist" (Velescu, 1996, p.72), an "artist-philosopher looking for primordial forms" (Jianou \& Noica, 1976, p.19), an exponent of a "culture, non-adherent to creation and history", an "artist of religious category" (Fondane, 2008, p.29, p.70), drafted into esoteric sciences and world mysteries, who "left significant traces in the art of the $20^{\text {th }}$ century" (Grigorescu, 1999, p.12). Having been coherent and persistent with his archetypal stock of motifs that were "projected into universal" (Comarnescu \& Eliade \& Jianou, 1967, p.5), the artist organized his entire creation into a "recurrence of symbols" (Fauchereau, 1995, p. 61) suggested by an open spiral. When Brancusi forged his own path and left his mentor, he uttered the memorable words "In the shadow of big trees grass never grows" (Zărnescu, 2004, p.23). Respectfully, "primitive, cubist and Hellenic seem to be the three dimensions through which Brancusi took distance from his master, Auguste Rodin" (Geist, 1973, p. 130). He experienced an "incontestable victory" (Pandrea, 2009, p. 48) through sculptures like Pray, and Sleeping Muse, which "contain in their simplified forms the beginnings of European modern sculpture" (Grigorescu, 1999, p.30). A significant case in point was the conflict with American custom authorities in 1927, when he did not get the accolades he expected for artistic qualities of one metal sculpture called Bird in Space. Therefore, a skirmish led him to a legal battle (Fondane, 2008, p.29; Devereaux, 2011, pp.15-21) which was settled in favor of Brancusi and his agents. Temple of Love, a project commissioned by an Indian Maharajah in honor of his wife, was not completed - he went as far as doing sketches of birds in flight. After the Second World War, tensions with Romanian authorities took a turn as the communist and pro-Soviet government replaced the monarchy. Because Brancusi did not fit into the ideological grid of proletcultist art, academic and political authorities (Brezianu, 1998, pp.12-13; pp.55-56) rejected his offer to donate all his drawings, pictures and sculptures to the Romanian nation. He then secured his French citizenship in the last five years of his life and left his entire establishment of workshops to his country of adoption.

Despite international recognition, over time his art has been perceived, in a polarizing manner. At the height of Stalinist authoritarianism, there was an overt attempt to turn Brancusi's works into scrap metal. However, Nicolae Ceaușescu's nationalist communism sought to instrumentalize Brancusi's work, to hijack his message and turn it into a symbol of Romanian nationalism. This shaped the debate between an indigenous mythologized perception and an avant-gardist or innovative interpretation of his art. After 1989, Brancusi's art was generally recognized by the Romanian cultural establishment as 
an international phenomenon. However, national nostalgia and a temptation to mythologize him did not fully disappear from the post-communist art world. Critics still regarded the sculptor as a figure of national importance, an exponent of a "culture, non-adherent to creation and history", an "artist of religious category" (Fondane, 2008, p.29; p.70). Nonetheless, with time, such sentiments of Brancusi became marginal, despite that today he is internationally recognized and acknowledged as an avantgardist founder of universal sculpture.

Even though digital television and social networking have boomed in Romania, where the highest speed of internet is unanimously recognized and big IT companies are operating, virtual arts dissemination has not been stable. This is because of minimal incorporation of cultural diplomacy and arts management knowledge in the formulation of public policies. Although some dozens of documentaries have been created and some media events have been organized in the last years for dissemination, digitally and online, Brancusi's reception in virtual environments has suffered from inconsistency, mythologization and political ideologization.

\section{Cultural policies development in Romania today.}

Numerous papers have been written on cultural diplomacy, management and marketing (Dragićevićšešić, Mihaljinac and Rogač, 2017), heritage (Ashworth, Graham and Turnbridge, 2007; Kalay, Kvan and Affleck, 2008), media anthropology (Munn, 2006; Pink, 2006; Rowels and Brown, 2017; White, 2003), discourse strategies and intercultural communication (Fairclough, 2004; Foucault, 2003; Manovich, 2001; Munteanu and Todi, 2011; Wood, 2006).

On the one hand, the Romanian Cultural Institute has acted as the main promoter of Romanian culture through its headquarters in Bucharest with subsidiaries in most capital cities in Europe, the Americas and Asia. On the other hand, inside Romania today, the Ministry of Culture and artists' associations have not succeeded in defining or implementing effective cultural policies based on the participation of civil society, independent professionals and unions which can collaborate to bring about cultural progress. Digital media have revealed avenues through which culture can be conceptualized, communicated and promoted. However, in Romania, the nature or content of cultural policies on cultural diplomacy and media depend on the caliber of the participants, budgets, time invested in preparations and on the targeted audience. Low budgets, centralized and ideologized policies, minimal insertion of modern concepts of cultural management as well as of digital and media discourses have delayed development of cultural diplomacy in both digital and real environments. Creating communities of "migratory audiences" (Appadurai, 1996, p.45) which have been enacted in a global and virtual context works better in politics than in culture because this type of media promotion can potentially block other relevant and subtle messages. The ability to conceptualize ideas and represent them in digital form implies "transcoding" (Manovich, 2001, p.21), making it possible to manipulate information in both spatial and temporal dimensions. When information is transmitted to remote and unknown viewers, it might be interpreted in various ways. Thus, the digital environment is a powerful platform to manage content in creative ways and to strategically channel opinion and thought on cultural policy development to a global or local audience. Digital media and social networking have become platforms for creating and publishing content through broadcasting that gives the main power to institutional and political communication. Therefore, the discourse and messages encoded in language might acquire a force of persuasion that designs and reshapes the 
virtual communities willing to click a link or to use the remote control for selecting a channel to satisfy their cultural expectations and tastes. What is currently lacking in Romanian cultural broadcasting is well thought-out, collaborative strategies and synergies to develop policies that will match the possibilities offered by virtual environments.

\section{Cultural diplomacy through digitalization and media. Brancusi's case in current Romanian policies}

Using an artist's image and prestige to develop cultural diplomacy posthumously clearly confirms the possibility of failure or success, depending on the strategies employed to use "political agency for culture" (Vickery, 2017, p.45). Evidence to support the hypothesis that there is not enough development of cultural diplomacy through digitization includes some "media events as live broadcasting of history" (Dayan and Katz, 1992, p.5). These have been champanioned by public sector and private entities. Such initiatives include the following:

a) a national fund raising campaign organized to bring back to the country one of the artist's masterpieces

b) an architectural project meant to extend the County Museum of Arts in Craiova

c) a section of digital sculpture added to the traditional workshop organized in Târgu-Jiu

d) a digital and networking festival that has been broadcasted in a combination of online and in situ locations, namely the appointment of an Ambassador to Brancusi.

Advocating the arguable idea of infusing his art into Romanian mythology does not open an intercultural dialogue on the innovative dimensions of Brancusi's art. Nor does it operate with soft power approaches to culture supposed "to seduce the audience rather than coerce it" (Savić, 2017, p.235). In 2016, a campaign started to bring back to Romania one of Brancusi's sculptures, The Wisdom of Earth. The noble initiative, which combined fundraising and was supported by a government donation suffered from inconsistency. An iconic Constantin Brancusi sculpture became the unexpected center of controversy after it came to light that the Romanian government had delayed returning more than 1 million euros in donations following a failed crowdfunding campaign to buy the artefact. Officials in Bucharest rallied the Romanian public to raise funds for the modernist masterpiece, using the slogan, "Brancusi is ours." But when the fundraising drive collapsed in 2016, the Romanian government decided that the donations would instead remain theirs until the end of 2017. The masterpiece, which shows the stylized figure of a young woman with her knees drawn into her chest was considered, by many, to be one of the Romanian artist's defining works. It was put up for sale with an 11-million-euro price tag in 2016. Businesses and individuals were asked to help raise the remaining 5 million euros, with more than 100,000 people donating to the cause. The drive failed to hit its target, instead producing just $1.2 \mathrm{~m}$. The disappointing results came despite a last-minute rush of donations from outraged Romanians after the Russian embassy in Bucharest publicly gave 100 euros to the cause. The Romanian government went on to pledge more money for the sculpture, but saw the idea defeated in the country's parliament. Officials say that they are now negotiating with the sculpture's owners in a bid to further drive the cost down. Working with emotions and ideology, rather than developing and presenting a professional message, meant to underline the importance of Brancusi's sculpture in national cultural heritage, the campaign organizers failed to collect enough money to buy the sculpture from the person who owned it. This underscores the fact that in order to prevent ideological dependence of one culture on another, a government should have clearly defined strategies for international cultural policies. 
Although people in Romania spend increasingly large amounts of time listening to radio, watching television and surfing the internet (up to $80 \%$ of the population), digital mass media has not yet become a medium for forming national cultural identity. The majority of cultural programs currently broadcast in Romania are based on consumerism and folklore, with the arts relegated to a range of representative roles, from state-sponsored cultural activities to private projects. Even still, interest in the arts has become seminal in cultural diplomacy, but the content and the quality of messages conveyed through digital media suffer from the insertion of political ideology, nationalistic mythologization and discourses focused on the specificity of Romanian national identity.

Discontinued in 2013 and resumed in 2020, the International Symposia, (organized by the Center of Research, Documentation and Culture Promotion in Târgu-Jiu, Gorj), has added a section of digital sculpture in which Romanian and international artists from neighboring countries participate. Except for a short coverage of arts media news which was broadcast through a regional subsidiary of TVR 3 , a Romanian television channel which focuses on regional events, digital sculpture has not benefited much from media coverage.

Other media events conveyed the same non-professional discourse as an expression of centralized and ideologized government cultural policies. When Romanian officials appointed pop star Irina Rimes as Honorary Ambassador to Brancusi, hoping that she would give Brancusi a new lease on life amongst Romania's youth, a big scandal ensued. The young singer rose to fame in Romania in 2016 thanks to her melancholic single "Dreams" and to two albums that gathered over 250000 YouTube subscribers, making her one of the most prominent pop-stars on the Romanian music market. A conference launching the project for Artist's National Day was timed to fall on the artist's birthday, February 19. Perhaps predictably, it sparked scandal and reinforced divisions in Romania's cultural landscape. With a dose of naivety and sincerity, Rimes referred to familiar works attributed to "Mr. Brancusi's" creation which make Romania known in the world. Although an official appreciation came from the Prime Minister, who supported the government initiative, Irina Rimes' vague speech generated an uproar in the national press and on social media. It did not accomplish the intended goal of enhancing a sense of virtual community and togetherness. Instead, it reinforced the fact that there is division in the meaning conveyers and virtual audience reception of the Romanian government's messages. This brought about criticism from high-profile journalists who made disparaging comments about the Minister of Culture, mocking him for his ridiculous choice and pinning high hopes on a singer who did not have enough background knowledge to speak with appropriate public impact. The organizers, mostly the Minister of Culture, Irina Rimes as the main Ambassador and indirectly, the Prime Minister as a political supporter, displayed a lack of intercultural competence and an orientation towards a paternalist model for promoting culture through media. Though free access to an appointed "ambassadors" social network has been provided to allow potential cultural partners to meet on a regular basis to modify ideas, the flow of information has remained unfocused. With minimal preparation and inadequate time, the media event organized by the Ministry of Culture has not accomplished any meaningful impact. Irina Rimes' speech was poor and inadequate for the context and the only successful aspect as reported by the officials who did a follow up was a significant increase in the number of visitors who accessed her Facebook and Instagram pages. However, collecting polling data by using the number of visitors to her social networking pages was the main method to measure the soft power of a cultural diplomacy event. The online cultural manifestation does not reflect any target groups' measurable feedback. As a modality to enlist by virtual means a mass audience made of 
followers, the singer has posted some of her pictures next to the Endless Column in Târgu-Jiu. The invisible audience willing to access a website or a profile on Facebook highly overlaps with indefinite groups that can be called virtual minorities. Discourse on media events as modalities of broadcasting history is instructive because it not only reveals the differences between liberal and centralized models of practicing cultural diplomacy, but also the gap between journalism and social sciences. As demonstrated by this appointment of an honorary ambassador, lowering all semantic, syntactic and pragmatic standards of media broadcasting through social networks, is a glaring example of a weak exercise in cultural diplomacy and communication. Involving popular artists as main organizers and sponsors without taking care of the quality of messages being conveyed, reduces all endeavors in cultural diplomacy or marketing to a political spectacle. When interpretation and reception are mediated through digital means and social networks, the receptors are divided in groups and segmented by cultural and ethnic background. In this kind of context, communication is essential, and the idea of national media coverage weakens the degree of political manipulation or persuasion.

The digitalization turn shows how media and networking can contribute towards satisfying the contemporary cultural needs of people of all generations. Although cultural programs broadcast through radio and television have lost a significant part of their audience, internet transmission through social networks may reach significant target groups created by imaginary communities and a virtual audience. Studies on governmentality have highlighted the fact that soft liberal models of online broadcasting are powerful and are governed by freedom and choice. Cultural diplomacy, as operating with soft power and discourse strategies, uses different forms of communication. Policy makers can consider carefully constructed methods of communication to promote an artist to a point where he is elevated to the status of a national icon, symbolizing key aspects of national heritage. However, when it comes to promoting sculpture internationally, using arts as "icons of identity, which were always expected to tell us who we are and where we stand" (Belting, 2000, p.57) does not come down to simply capturing the right message. It remains a regional and an ideological institutional behavior that is meant to show an interest in recovering the artist's memory as an expression of an ideal Romanian mentality. Borrowing from previous political systems, the cultural managers of the public system in Romania (mainly consisting of the Ministry of Culture and a network of County Centers for the Development of Artistic Creation and Patrimony Preservation) have not yet experienced the paradigm shift that will allow liberal models of managing and marketing culture. Their focus remains the conservation of intangible and material heritage without considering different perspectives or opinions from competitors. Therefore, the transmission of art productions through digital channels and social networks mystifies national narratives, which are supposed to serve as mobilization instruments for contributing to the revival of national consciousness. When involvement of other players is prohibited, government-centered policies become increasingly resistant to new ideas.

As online meaning should be reconstructed and negotiated (Castells, 2007, p.252), the intense mediation of political discourse and its reliance on how media strategies are created can make an audience confused and unable to differentiate between advertisements, politics and media communication. Targeting people of different ages and cultural backgrounds with such media and political events has not promoted culture, but rather, generated a disruptive and divided audience of mass-culture "experts" who journalists and professional art critics must contend with. Wanting to exert power over the people and to grant power to those who might be willing to access a link, the official messages sound more "coercive and manipulative" (Wood, 2006, p.18) than convincing. Promoters of cultural activities should communicate clear messages through media to secure virtual space. Anthropology raises important questions on cross-cultural communication, and in the process 
of production and reception, media discourse should generate "inter-discursivity and dialogicallity" (Fairclough, 2004, p.43). By sharing similar values, virtual communities can move from participants playing only a marginal role, to engaging in active dialogue as artists and cultural activists. Thus, they will be able to create collaborative structures that will promote cultural diplomacy effectively. As an expression of social practices, the texts broadcast through media belong to genres of governance that sustain the institutional structure and make local events reverberate towards a national or even international scale. Instead of bottom-up soft power, the Ministry of Culture used a top-down centralized discourse that infringed on the quality, quantity and cooperation principles of communication (Grice, 1975). The capacity of Romanian authorities to transcode information from one medium to another, and to represent concepts in attractive digital forms have been minimal. Instead of organizing events to bring participants together and break the monotony of daily life, there have been timid attempts to create virtual communities through digital media. Such feeble attempts have so far failed to convey a feeling of unity.

In Romania as well as in other post-communist countries, media coverage of cultural diplomacy and management has frequently been reduced to "theatrical production of the truth behind the disease" (Foucault, 2003, p.50) and media consumptions, mentalities and administration inefficiency (which correlates with corruption) have taken root in media and social networking. Without a strong cultural orientation in both content and discourse, virtual communities have encountered some biases in communication. These biases have blurred the interdependence between formal and informal use of language. Dysfunctional ties coupled with political changes have compounded the effects of multiple interference within the virtual environment, making it a niche for developing a digital broadcaster and virtual audience. Through this semantic mapping of cultural diplomacy, some cognitive frames, narratives on identity and the people selected to broadcast them through the familiar and vicarious experiences of life, work together to lower the impact of discourse destined for people. The production of virtual content is achieved by "reinventing signs" (Hammer, 2005, pp.260261) and transmitting them through different channels like media and social networking.

Today, the general cultural landscape in Romania is dominated by competition between an official governmental culture, which is managed and marketed by a system of cultural bodies, civil society or private companies. All these entities organize art festivals of film, music and theater. Said cultural bodies are heavily centralized and under the direct control of the Ministry of Culture. Due to inadequate knowledge and skills in cultural management, ill-defined criteria for selecting cultural ambassadors and a lack of institutional cooperation, the cultural activities organized by the public sector have had a low impact and little visibility. There is a disparity between the political establishment which designs the cultural policies and the implementation of cultural practices. In addition, operating in a space that is not systematic, is inconsistent, and allows only heavily centralized collaborations, the government found itself in a "crisis of political legitimacy" (Castells, 2007, p.239) that hindered the streaming of the right content to online social networks.

Networking also modifies the relations between micro- and macro-social groups, reducing the importance of dialogue as a cultural pattern, important for the development of cultural identity. The cooperative aspect of communication makes the virtual space "a collective mental arena, a place that the participants share with their minds" (Wertheim, 1991, p.231). Effective participation should be brought about by the multimodal texts that are transmitted through media. 
Content orientation implies appreciation and use of intercultural knowledge (at least locally). The preparation process for designing and implementing projects - scheduling activities, budgeting and allocating human resources, is essential to successful cultural production. It requires courage and a willingness to take risks by both the sponsor and the sponsored.

Some initiatives by private and civil society are better at showing how Brancusi's work was adapted to the current cultural context and marketed digitally. Professional and international attempts to commemorate this artist's life and claim his internationally recognized heritage by underlining the classic and innovative features of his works are worthy efforts. Some e-books, short films and TED talks have benefited from the background knowledge and the right media discourse encoded in multimodal texts. The e-book Brancusi: A Sculptor from the East (Șușara, 2020) brought, in its economy, a great balance between the two main paradigms of reception-the classic and the innovative one. In the same vein, a Romanian architect, Dorin Ștefan has succeeded in recovering symbols in Brancusi's sculpture in architecture - among them a cube, a bird in flight and the ovoid. At the Mondial Exhibition in China 2010, he suggested the recreation of avant-gardist motifs inspired by Brancusi's project about the Temple of Love in Indore, all transposed in the modern environment and virtual space. The Romanian Pavilion at this exhibition consisted of a cube, the interior of which had an ovoid (a hole in the roof), which caused the light to make a brilliant holographic depiction of one of the sculptor's recurrent masterpieces, Măiastra (A Bird in Flight). Due to his persistence that architecture is "inhabited sculpture" Ștefan transfered Brancusi's avant-gardism into a digital and futurist experience by suggesting an extension to the Museum of Contemporary Art in Craiova. Conceived as a hypermodern replica of the same temple projected by Brancusi in India, the Eastern wing of the Museum was thought to have an underground entrance into a glass prism, and at the center an ovoidal shape. The ideas of spiritual gravitation and flight (which inspired Brancusi's work through his entire life) might be suggested here by a three-level building connected by a glass elevator, that transports a visitor from the basement decorated with sculptures, to the second floor that is garnished with digital copies of Brancusi's masterpieces from the George Pompidou Cultural Centre, and some holographic depictions of his birds on the third floor. It evokes the sculptor's importance in an avant-gardist artistic context (while using a brand with international impact to reach the target audience.)

Corporate and civil takeover of the cultural production in virtual spaces might result in the creation of media events that provide an opportunity for collaboration and communication where the spectacular and public messages come together. Such partnerships between authorities and specialists in cultural management and social network might create a framework for designing and implementing successful projects. Cultural policies that are created without the participation or contribution of civil society lack the vibrancy, inspiration, and originality which civil society input can bring. When independent and private sector professionals who are familiar with arts are involved in teams, they fare very well both in-situ and in online events. The independent sector of culture directs its strategies toward the production of public goods whose content and discourse functions as a catalyst for the diverse interests and voices of the citizens. It develops models of collaboration which might regularize the cultural environment and make it more competitive and profitable. With such communication and collaborative energy, this active part of society stimulates and creates vivid relations and strategies that allow real and virtual communities to cultivate their aspirations and nurture their values openly. In summary, not only do all digital communities have discursive mechanisms as subsets, but bias in content and non-adaptation to context result in many consequences for the recipient. To date, media events organized by public authorities in Romania have not allowed any strategies that are characterized by negotiation among organizers, broadcasters or audience - which is unfortunate since they need to partner up for cultural diplomacy to be realized. Battling over individual representation 
and interpretations of an event's significance, as happened in the case of Irina Rimes, are a waste of valuable time.

\section{Conclusions}

After the efforts of the 1990s to bring about cultural diplomacy, marketing and arts have vacillated between fragmentation and tension. In the wake of great accomplishments in academia and art festivals, public policies implemented by the Romanian Cultural Institute have tended to hinder government efforts to shed light on the role of culture in international relations and in arts marketing. The development of digital media and internet resources has shifted the focus of policy makers onto performance art like dance, festivals, film, and theater, while the discreet and silent ones - such as architecture, monuments and sculpture - have been held back by unclear cultural policies and low budgets.

Culture and cultural diplomacy are often considered to be unifying, mediating and supporting vectors in the process of global digital communication. Romanian cultural authorities mostly represented by the Ministry of Culture and the Romanian Cultural Institute have, so far, fostered ideological, mythologizing and nationalistic interpretations of art forms and showed less interest in pointing out the avant-gardist and international dimensions of Brancusi's legacy. There is a need to collaborate in designing and implementing projects that promote and celebrate culture and artists, or create dialogue with key players from civil society and the private sector, so that everyone works from the same perspective.

Even though Romania has one of the best internet infrastructures and speeds in Europe, media development remains local and marginal in terms of cultural management, international visibility and impact. Short-lived ideological and unpredictable cultural policies designed by often-changing governments and short-lived careers in the post of leadership in ministries of culture have brought varying and disconnected political agendas into the mix - and, consequently, a lack of coherence in terms of strategy formulation and lack of sustainability.

Media broadcasting still uses centralized models to develop projects, excluding cultural operators, artists and managers. This is unfortunate since these players can bring about desired changes. The limitation of broadcasting to the regional media market (usually in the national language) and to an elite target audience neither succeeds in the revival of the prestige of consecrated artists nor does it promote the up-and-coming artists from the younger generation.

Cultural diplomacy should be a part of the general policies concerned with bringing citizens together as individuals and as groups who are targeted by media and social networks.

Appointing professionals from different backgrounds and integrating them into working teams, using the soft power of cultural diplomacy and setting the right terms of discourse, might all offer lasting solutions to existing challenges and help to foster a sense of community and togetherness. All this might also reduce light-hearted viewing of art documentaries on television (and related social networking) and emphasize the importance of the soft power of cultural diplomacy. 


\section{References}

Anderson, B. (2006). Imagined Communities. Reflections on the Origins and Spread of Nationalism, London and New York: Verso.

Appadurai, A. (1996). Modernity at Large. Cultural Dimensions of Globalization. Minnesota: University of Minnesota Press.

Ashworth, G.J., Graham, B and Turnbridge, J.E. (2002). Pluralising Past. Heritage, Identity and Place in Multicultural Societies, London and Ann Harbor: Pluto Press.

Belting, H. (2000). "The Visual Arts Today: Experiences and Expectations", in Wil ARTS, 56-67.

Brezianu, B. (1998). Brâncuși în România [Brancusi in Romania], Bucharest: All.

Castells, M. (2007). "Communication, Power and Counter-power", in the Network Society' in International Journal of Communication, 1, 238-269.

Comarnescu, P., Eliade, M et Jianou, I. (1967). Témoignages sur Brancusi. Paris: Arted, Ėdition d'Art.

Dayan, D and Katz, E. (1992). Media Events. The Live Broadcasting of History, Cambridge, Massachussets, London, England: Harvard University Press.

Deac, M. (1982). Brâncuși. Surse arhetipale [Brancusi. Archetypal Sources], Iași: Junimea.

Devereaux, C. (2011). "Is art a fruit or a vegetable? On Developing a Practice-Based Definition of Art", in Studia Universitas Babeș-Bolyai. Philosophia, Cluj-Napoca, 56(3), 7-25.

Dragićević-šešić, M., Rogač Mijatović, L and Mihaljinac, N. (2017). Cultural Diplomacy. Arts, Festivals and Geopolitics, Belgrade: Creative Europe Desk and Faculty of Dramatic Arts. Print.

Fairclough, N. (2004). Analysing Discourse, New York: Routledge.

Fauchereau, S. (1995). Sur les Pas de Brancusi : De Tîrgu Jiu à Philadelphie, via l'impasse Ronsin, Paris : Hermann, Editions Cercle.

Fondane, B. (2008). Brâncuși [Brancusi], Bucharest: Limes.

Foucault, M. (2003): Biopolitică și medicină socială, Cluj: Idea Design and Print.

Geist, S. (1973[1967]). Brâncuși. Un studiu asupra sculpturii [Brancusi. A Study of Scupture] Trans. by Andrei Brezianu. Bucharest: Meridiane.

Geist, S. (1978). Brancusi/The Kiss. New York, Hagerstown, San Francisco, London: Harper \& Row Publishers.

Grigorescu, D. (1999). Brâncuși și arta secolului XX [Brancusi and the Art of 20th Century]. Bucharest: 101+ Grammar.

Hammer, A. (2005). "Weaving Tricksters. Myth and Tribal Encounters of the World Wide Web", in Rothenbuhler and Coman (Eds.): Media Anthropology. London: Sage Publications.

Kalay, Y.E., Kvan, T and Affleck, J. (Eds.). (2008). New heritage. New media and cultural heritage, London and New York: Routledge.

Jianou, I and Noica, C. (1976). Introduction à la sculpture de Brancusi. Paris: Arted, Ėdition d'Art.

Morphy, $\mathrm{H}$ and Perkins, M (Eds). (2006). The Anthropology of Arts. London: Blackwell Publishing.

Munn, N. (2006). "Visual categories: An Approach to the Study of Representational Systems", in Morphy and Perkins (2006), 326-339.

Mladin, C.I., Munteanu, A.M and Todi, A. (2011). Risk, Language and Identification in the Network Society. The Impact of New Media on Intercultural Communication, Bucharest: Cartea Universitară.

Pandrea, P. (2009): Brâncuși. Amintiri și exegeze [Brancusi. Memories and exegeses]. Bucharest: Vremea.

Pandrea, P. (2010). Brâncuși. Pravila de la Craiova [Brâncuși. The Code of Laws from Craiova]. Bucharest: Vremea.

Pink, S. (2006). The Future of Visual Anthropology: engaging the senses, Oxford: Routledge.

Rothenbuhler, E. W. and Coman, M. (Eds.) (2005). "The promise of media anthropology", in Rothenbuhler and Coman (Eds.): Media Anthropology. London: Sage Publications.

Rowels, D and Brown, T. (2017). Building Digital Culture. A Practical Guide to Successful Digital Transformation, London: Kogan Page.

Sartori, G. (1997). Homo videns. Televisione e post-pensiero. Roma-Bari: Giussepe Laterza \& Figli. 
Savić, M. (2017). "Contemporary Art Practices in the Conduct of Cultural Diplomacy", in Dragićević-šešić, Milena., Rogač Mijatović, Ljiljana., Mihaljinac, Nina (2017), 229-239.

Spear, A. (1969). Brancusi's Birds. New York: New York University Press for The College of Art Association of America.

Stanculescu, N. (1981). Brâncuși [Brancusi], Bucharest: Albatros

Șușara, P. (2020). Brâncuși. Un sculptor de la răsărit [ Brancusi. A Sculptor from East], Bucharest: Monitorul Oficial R.A.

Tabart, M. (1995). Brancusi. L'inventeur de la sculpture moderne. Paris: Gallimard/ Centre Culturelle Georges Pompidou.

Tucker, W. (1974). The Language of Sculpture. London: Thames and Hudson.

Velescu, C-R. (1996). Brâncuși Alchimist [Brancusi Alchemist]. Bucharest: EDITIS.

Vickery, J. (2017). "Since Internationalism: Diplomacy, Ideology, and Political Agency for Culture", in Dragićevićšešić, Milena., Rogač Mijatović, Ljiljana., Mihaljinac, Nina (2017), 35-49.

Wertheim, M. (1991). The pearly gates of the cyberspace, London: Virago Press.

White, S. A. (2003). Participatory Video: Images that Transform and Empower. Thousand Oaks: Sage Publications. Wood, N. (2006). Describing Discourse. A Practical Guide to Discourse Analysis, New York: Oxford University Press. Zărnescu, C. (2004). Aforismele lui Brâncuși [Brancusi's Aphorisms], The Fourth Edition, Prefaced by Marin Sorescu, Cluj-Napoca: Dacia. 